\title{
SEMINARIO CRUELDAD Y PULSION DE MUERTE
}

\author{
FERNANDO ULLOA \\ Charla en la Facultad de Psicología de Rosario el 28/08/04
}

El humor conjetural, la clínica, el abordaje metapsicológico de la crueldad y algún esbozo que estoy
trabajando acerca de la articulación de la crueldad con la pulsión de muerte.

Agradecemos especialmente a Pedro Ulloa por la cesión a nuestra revista del material revisado por el autor.

Para no correr tantos riesgos, el destino final de esta charla es ciertas conjeturas que estoy haciendo en relación a la crueldad que en cierta forma me permitiría, son algunas conjeturas que tengo que chequear más en la clínica, que me permitirían articular la crueldad a dos categorías que se pueden identificar la pulsión de muerte. La que llamaría pulsión mortífera, muy ligada a la crueldad, y la pulsión más sutil de la pulsión de muerte como par antitético de la pulsión de vida y a su trabajo más sutil, casi diría más dialéctico con la vida.

Hay una conferencia de Derridá, que la dio hace dos años creo, en el contexto de lo que se llamaron los Estados Generales, no sé si ustedes tienen algunas información de eso, es una convocatoria no institucional a los analistas, analistas e instituciones, que surgió en cierta forma como una respuesta a ese analista, no me acuerdo cómo se llamaba, brasilero, un médico que participó en sesiones de tortura y que era alumno de la IPA, de la institución, porque él tenía al didacta, tenía supervisor, el momento en que esto ocurría el presidente de la IPA era un argentino, Etchegoyen, no hizo nada. Una brasilera escribió todo un trabajo, víctima en cierta forma, ¿cómo se llamaba este hombre? Si no se llamaba Lobo andaba por ahí. Un nombre parecido. Lobo (Amilcar), era cruel. En cierta forma de ahí surgió un cierto movimiento, quizá el país donde más se ha trabajado esto de los Estados Generales, es esa instancia en la revolución francesa que fue superada, donde se convoca el clero, a los militares, a la nobleza, a la burguesía, como una instancia de último momento pero que fue superada por los sujetos, por los individuo, esa era la idea.

Derrida daba una conferencia sobre la crueldad, yo tenía que coordinar esa conferencia, después no lo pude hacer, por problemas personales no pude viajar, y él hace una observación, es buena y está publicada en castellano, él tiene una observación. Dice que el psicoanálisis tiene una resistencia autoinmune, dentro mismo del psicoanálisis, a abordar específicamente, él dice abordar el campo social, pero específicamente abordar la crueldad, consigna qué es la crueldad. Incluso hay otra cosa que voy a señalar, que me pareció inteligente de Derridá, que es cuando discrimina entre la crueldad, que viene de crúor, sangre, sanguinolento, derramamiento de sangre, y el sufrir cruelmente se adverbializa, se hace adverbio, sufrir cruelmente, ya no hay sangre derramada. Un ejemplo puede estar dado por las víctimas de la represión integral, sufrieron la crueldad con sangre y muerte. Los familiares totalmente impotentes sin saber, siguen sufriendo cruelmente, quiere decir que aunque no haya sangre el sufrimiento puede ser atroz.

Entonces a mi me parece que hay varias razones por la cual el psicoanálisis tiene esa resistencia auto inmune. Hay un tipo de modalidad de clínica adecuada para atravesar esa y muchas 
otras resistencias, pero básicamente la clínica necesaria para enfrentarse con lo original, con lo nuevo, con lo que no se ve. Para que yo me pueda explicar porque yo trabajé años sobre la ternura como un telón de fondo, para trabajar en cosas de derechos humanos, en torturados, en chicos secuestrados, y la ternura me servía como un telón de fondo, pero nunca se me ocurría sustantivizar la crueldad, tomarla como un sustantivo. A Freud le pasó otro tanto, hasta el año '20 él estaba trabajando en la pulsión de vida y un buen día casi con escándalo para sus discípulos, para la teoría, abre el concepto de pulsión de muerte. Se podía decir que esto responde a los pares antitéticos pulsionales con que generalmente trabajaba Freud, pero yo creo que no, que ahí apareció algo que ya empieza a insinuarlo en el '15 con la guerra del '14, escribe un trabajo que es bastante importante sobre "La guerra, la muerte. Temas de actualidad" que no es el trabajo ya posterior de "El por qué de la guerra", que es lo que resulta -casi al final de su vida- de conversaciones con Einstein.

Entonces, voy a decir algo de esa modalidad clínica, a enfatizar particularmente algo que empecé a trabajarla hace unos cinco años -más o menos- cuando hice un trabajo sobre la metapsicología de perelaboración y después abandoné el tema -lo he recuperado últimamenteque es también un aspecto importante de la clínica-que por lo menos yo me identifico con ese aspecto- que se llama el humor conjetural, así que después que introduzca este tipo de clínica, quiero hablar del humor conjetural. Y recién después, el núcleo duro de la charla, son cinco páginas o un poquito más, les voy a leer al final una conferencia de un debate que en Barcelona tuve con un inglés que trabajó sobre la civilización y barbarie en el siglo XX en Europa. Entonces, yo partí de este texto, él partió de sus texto y después hubo un debate de bastante tiempo. Es un tema que me permite ajustarme y no dispersarme, acá en esto si tal vez me disperse un poco, para desde acá tratar - esto es un texto metapsicológico- de hacer alguna conjetura sobre la crueldad y pulsión de muerte.

Esta clínica, a la que yo aludo, necesaria. Cuando yo hablo de clínica, hablo de dos escenarios. Hablo de la práctica donde fue puesta a punto el psicoanálisis, que es la neurosis de transferencia, esa primera institución, la más legítima, que nos legó Freud, que es la neurosis de transferencia montada en los dos pilares, es decir la intención asociación libre, la asociación libre es una cosa imposible pero la intención es lo importante, hace a la diferencia en el analizante y la atención libremente flotante, otra imposibilidad en el analista que son los dos pilares, dos libertades la asociación libre y la atención libremente flotante, son dos libertades para la captura de lo que se llama neurosis de transferencia, aquellas viejas cosas que el paciente repite en su comportamiento y que es la posibilidad, Freud la tomó al principio como un resistencia, pero la oportunidad para ir resolviendo los viejos traumas que van haciendo o fundamentando lo que será después la gravedad de un paciente.

Cuando hablo de gravedad insisto en que gravedad es un abanico etimológico, fuerza de gravedad en un analista para sostenerse en el rol, en cualquier rol, sobre todo la fuerza de gravitación para sostenerse en un rol con la enfermedad, con la psicosis, con el amor de transferencia, para sostener un rol. El gravamen, o sea el costo que tiene-que también es una variación de gravedad- el costo que tiene, cualquier oficio viene asumido como una forma de vivir, una forma ética de vivir, un costo, un costo que hay que pagar y que bienvenido que se lo pague. La gravidez también en nuestro oficio, pero también en otros oficios, la vida nos va fecundando. Pichon Riviére tenía una frase medio graciosa, la deben conocer, él decía que a sus pacientes pretendía lograr lo que lograría un buen profesor de inglés que era el inglés básico, bueno, análisis básico. Porque decía que una persona que aprende inglés básico y circula por una comuni- 
dad que habla inglés, la calle le enseña inglés. Lo mismo pensaba él del análisis; que cuando se pueden echar los fundamentos básicos de una postura, de la curiosidad por uno mismo, tal vez cuando se puede echar las posturas de alguien que pueda sostenerse con suficiente fuerza de gravedad en la vida, gravitación, cuando pueda tener su gravamen, bueno la vida le enseña. Es un concepto importante, en realidad para mí un análisis es la posibilidad de instaurar el propio análisis. Que uno lo que lee, lo que escucha, lo que piensa distraídamente, vaya teniendo valor interpretativo, valor de revelación sobre uno mismo.

Esto está ligado a una cosa que me gustaría hablar pero que no voy a hablar, pero me gustaría, es un texto que escribí hace poco, el texto se llama Las fuentes del Psicoanálisis, y yo me decidí a hablar de cómo llegó la idea del psicoanálisis a mí, o algo parecido al psicoanálisis, y fue leyendo, a los 19 años, cuando empecé mi formación universitaria médica, me encontré con un libro que para mí fue muy importante, nunca lo volví a leer por cierta idealización seguramente, un libro de Stefan Zweig en la autobiografía que escribe y donde dedica cuatro páginas a Freud, la escribe en Londres después que ha muerto Freud, cuatro páginas que fueron extraordinaria. El texto dice: "Conocí a Freud...” ¿Por qué? Porque en ese texto, en la página 330 de ese texto, de esa autobiografía, El mundo de ayer, se llama, Stefan Zweig dice... conocí a Freud.

Lo importante fue que días después me volví a cruzar con Freud en una librería en un libro de Thomas Mann, aquel autor que yo ya había leído, Montaña mágica, La muerte en Venecia, y entonces en un momento dado él dice, emplea una frase de... una conferencia que publica a los 80 años de Freud, y él dice que finalmente entendió lo que era el psicoanálisis yendo a un discípulo algo desagradecido pero muy inteligente, lo nombra a Jung. Eran bastante rivales incluso enojosamente rivales. Por neurosis de los dos. Entonces cita esa frase, un texto de Jung que dice: mucho más interesante, mucho más apasionante, mucho más directo -la traducción es medio cacofónica- la conferencia fue en el 36, se tradujo a Buenos Aires en el 37. Cosa curiosa porque todavía no había nada escrito sobre Freud. Las obras de Freud no estaban. Mucho más interesante y directo que tomar cuenta de lo que nos disponemos a hacer, es advertir lo que nos sucede. Vale decir tomar cuenta de lo que nos está sucediendo.

En este sentido, hablo yo, de cómo la vida en ese análisis básico lo va analizando a uno, lo que le va sucediendo. La frase concreta de Thomas Mann, la toma de Schopenhauer, es trazamos lo que nos sucede. Esto es relativo. No siempre trazamos lo que nos sucede, pero no cabe duda que cuando uno toma en cuenta -otra digresión- yo voy asociando y me parece que es la única forma con que puede hablar más o menos suelto. Recuerdo que Mimi Langer me enseñó una frase, ella se había ido al exilio, yo estaba acá, no quería irme, fanfarroneaba con el coraje personal pero realmente estaba en peligro hasta que en un momento dado me di cuenta que tenia que irme. Ella me decía una frase de un maquí que lo capturan y va camino, en un tren de la muerte, camino a un campo de concentración. Este maquí dice..., es una desgracia estar en ese tren, lo que le está sucediendo, también podría decir lo que le está aconteciendo también; el acontecer es un verbo que tiene más trascendencia a futuro, el suceder me remite más a lo que viene sucediendo a pasado. Entonces dice que intenta salvarse y que para salvarse tiene que saber cuando se subió a ese tren; entonces recuerda que a los 14 años va París a estudiar secundario, en pocas semanas un amigo lo lleva a una manifestación estudiantil, él se queda muy..., la revelación, otra forma de ver la colectividad de estudiantes, eso es suficientemente fuerte como para que este hombre llegara el período del nazismo y el maquí estuviera en la resistencia, entonces se da cuenta que él se subió a ese tren, que era una desgracia, que él se subió al tren a los 14 años cuando algo marcó su vida. En ese sentido trazamos lo que nos sucede. 
Seguramente se salvó.

Él decía, tengo que ser coherente, si quiero intentar por lo menos salvarme o vivir esta situación lo más coherentemente con mi vida. Seguramente llegaron las tropas rusas, las americanas, qué se yo, habrán tomado ese campo de concentración, se salvó.

¿Cómo hago para volver? Entonces yo decía que hay una forma de la clínica. Voy a hablar de la clínica, el humor conjetural y después me meto en esto. El humor conjetural, ahí me voy a detener un poco, es una forma particularmente importante, una disposición, para mí es una disposición ética pero es una disposición metodológica, para meterse con algunas cosas de difícil abordaje. Cosas que, hace poco recordaba una frase de Ortega y Gasset cuando dice "no hay ninguna razón para no emprender, o no intentar hacer, aquello que siendo necesario aparece como imposible". Ninguna razón para no intentar hacerlo. Es una frase que a mí me tocó hace muchos años también, quizá tuvo algún efecto, y yo acabo de decir que la asociación libre, es imposible asociar libremente, aunque yo demuestre lo contrario acá tal vez. La tensión libremente imposible. Pero el intentar hacerlo es lo que hace a la diferencia. En esto suelo recordar, algunos ya me lo deben haber escuchado varias veces, un libro de Bobby Fischer que se refiere a las aperturas de un partido, cómo se abre un partido de ajedrez muchas veces marca el destino. Traza lo que después va a suceder. Este libro se llama Mis sesenta mejores partidas incluyendo varias derrotas. Vale decir que nosotros tenemos derrotas en esos intentos pero esas derrotas abren derrotero, van abriendo la posibilidad.

Freud decía: es imposible gobernar, imposible educar, imposible analizar. Sí, es imposible en tanto uno no lo intente; entonces intentamos gobernar, la democracia es un intento continuo, la educación es un intento, el análisis es un intento que hace a la diferencia, que va abriendo caminos.

La frase que vamos a plantear ¿Qué tipo de clínica es a la que me ajusto?, no es una frase que leí hace muchos tiempo, la leí hace muy poco, el sábado pasado, tenía que cerrar unas jornadas sobre la risa, me habían propuesto que hablara sobre el humor, entonces yo titulé mi charla El humor ¿de transferencia o en transferencia?, jugando con el amor de transferencia o en transferencia. El amor de transferencia es todo lo que preside, que se despliega en esa institución de la neurosis de transferencia. El amor en transferencia es esas cosas apasionadas que pueden aparecer, apasionadas de odio o apasionadas de amor, tal vez apasionadas de erotización, en un paciente que esto fue lo que le pasó al socio de Freud, Breuer, cuando su primer paciente, Ana O, no solamente declaró su total amor hacia él y su pretensión de..., sino que empezó con una, tal vez más célebres embarazos histéricos. Vale decir hizo toda la somatización de un embarazo y Breuer se asustó, disparó con su mujer, se fue a Viena, abandonó esto, la paciente la siguió Freud. A veces son muy difíciles, el amor en transferencia; ahora, si la situación se maneja con humor, el analista no es un humorista; el humor conjetural -enseguida voy a meterme con estoes una forma muy próxima a la ternura. En el abanico entre la ternura y la crueldad el humor conjetural, enseguida voy a avanzar sobre esto, está más cerca de la ternura, está mas cerca del más remoto antecedente de la clínica que es la ternura. La ternura implica empatía, la madre sabe porqué llora el chico, la ternura implica abstinencia, implica lo que no se puede hacer. En el escenario de la niñez ni se sobre excita ni se sobre agrede a un chico. Entonces siempre que digo esto, ni se sobre agrede ni se sobre excita, alguien puede pensar, y alguien incluso me lo dijo, pero cómo ¿entonces se lo puede agredir y se lo puede excitar? Uno no lo sobre excita ni lo agrede. La vida tiene agresiones, la vida tiene excitaciones. La crueldad de la muerte, la crueldad del sufrimiento, la crueldad de una familia no necesariamente sin trabajo, pero imagínense lo 
que es un padre, ser padre y no tener trabajo, la crueldad de las situaciones manicomiales que pueden darse en un familia, encerronas trágicas, eso ya sería sobre excitar, pero eso está siempre. A veces trabajando en zonas de la pobreza uno ve en una habitación, diecisiete personas, el caso es bien concreto, y el abuelo está muriéndose, y los padres están cogiendo y bueno, y todo lo que puede estar pasando, pueden estar con hambre, eso es una situación limite, puede ser una situación límite, sin ser una situación límite, y en otras aún más; no son las condiciones en que la mayoría de nosotros vivimos, casi todos ...otra vez me fui.

Por qué quiero decir esto? Entonces cuando aparece alguna de esas antiguas que aparecen como facsímiles de la transferencia y aparecen algunas cosas incómodas, algunas cosas fastidiosas, la erotización de un paciente puede ser una situación de difícil manejo. Uno tiene cierta simpatía, tal vez la simpatía que no tuvo ese niño o niña siendo chiquito, muy apasionado por su padre o por su madre, con sus dos añitos o tres, y el padre y la madre miraban con simpatía eso y sin equívoco, sin sobre agredir y sin sobre excitar, miraban con simpatía eso. Cuando faltó esa simpatía, cuando a ese chiquito le nació un hermanito o lo que sea, y quedó totalmente excluido, muerto de celos y derrotado, esa situación aparece en la transferencia, repite en la transferencia pero no se repite como el fracaso, se repite como fue precisamente lo que terminó el fracaso, se repite. Entonces darse cuenta que el odio o el amor en transferencia es la pasión necesaria que un paciente tiene y que uno tiene que alojar, que uno tiene que trabajar para salir de un síndrome de padecimiento histórico, vivió en la noche de los tiempos. Ese síndrome de padecimiento que tiene tres elementos, lo vemos cotidianamente. Lo vemos en los grandes y lo vemos en los chicos, que es el acobardamiento de la derrota, el acostumbramiento a la derrota, el acostumbramiento a las condiciones de intimidación que rompen toda intimidad, el desadueñamiento del cuerpo que pierde contentamiento, y solamente se sabe eso, se trate de trabajar en la miseria con adultos o se trate de situaciones que también se dan en la vida cotidiana en condiciones mucho más propicias, y la posibilidad de salir de ese síndromes de padecimiento solamente a través de la pasión. La pasión cambia, troca la c de de padecimiento con la s de sufrimiento, el problema es cómo se encamina esa pasión, cómo esa pasión, esto sería largo decirlo, cómo de esa pasión se hace oficio, o se hace reacción, o se hace ideología, o se hace respuesta, se hace intento de resolver lo imposible. Ya sea el intento que hace un niño de resolver lo imposible a través de lo que luego será la novela familiar neurótica y toda la época de la fabulación, de los juegos, de los personajes imaginarios.

Bueno, la frase que yo leí, que me sirvió no para esa charla del otro día, del amor de transferencia, ahí redescubrí leyendo un antiguo trabajo mío, de 7 u 8 años, sobre la metapsicología de la perelaboración, después me meto con eso, me di cuanta que ya había empezado a hablar del humor conjetural.

La frase que me llevó a esto es la frase de un poeta japonés, poeta de los aikú, esos poemas muy cortitos, que se llama Bascho, que dice una frase interesante, dice: "no sigan las huellas de los antiguos, busquen lo que ellos buscaron”. A mi me resultó muy importante esta frase, es contradictoria. Si hay algo tiene el humor conjetural en la transferencia que es contradictorio. Por un lado él dice, aconseja, habla con sus discípulos, aconseja, son consejos, es algo que ya está en el saber popular, yo quisiera (...) esta frase (...) sino como una frase que en la clínica no se trata de seguir las huellas que ya fueron trazadas por nuestros antiguos, lo cual no significa el disparate y la necedad de que no hay que leer, al contrario bienvenidas las lecturas, pero no hay que perder la singularidad que nos lleva a buscar sus propios caminos; que a mi me llevó en un momento dado a trabajar la crueldad. Por supuesto, eso tiene antecedentes, no son gratui- 
tas esas cosas, tienen siempre una coherencia con alguna cosa, en mi caso fue la muerte de un hermano de una manera trágica; siendo yo chico, y siendo el hermano idealizado, el hermano envidiado. Bueno, pero eso es otra historia, pero siempre hay algo, la crueldad aparece de muchas formas, no necesariamente con sujetos crueles, aparece cuando la vida es cruel a veces por los equívocos o por la circunstancias que se van concatenando como fue precisamente lo que terminó en la muerte de ese muchacho de 10 años, cuando yo tenía 6 .

Es contradictoria esta frase, ven que yo voy y vengo, voy de la crueldad al humor, es que él dice aconseja, Bascho dice como sujeto, el enunciado dice 'no sigan las huellas de los antiguos, busquen lo que ellos buscaron', por un lado dice, sea libre siga su propio camino, pero por otro lado dice, ojo no hagan esto, hagan esto; hay una contradicción ya en la propia frase, pero además esta contradicción es la misma contradicción que (...) Groucho Marx para aliviar las cosas dice cuando dice una cosa tan contradictoria y tan sutil. El cuento lo conocen todos no tienen porqué reírse, dice que él nunca sería socio de un club que lo hubiera aceptado a él como socio. Es muy interesante. Lo traduzco a una experiencia personal inaugural. Yo había intentado analizarme con Pichon Riviere, lo había conocido, había quedado medio deslumbrado, ya era psiquiatra; había interrumpido el curso de postgrado podrido por ciertas redundancias de ese curso, pero me faltaba un mes y me peleé medio boludamente, hoy creo que no sabiamente, y me fui de ese curso cuando el profesor, después de las 17 clasificaciones japonesas, alemanas, qué se yo, de la esquizofrenia, yo digo ¿tiene alguna utilidad? Y él me dice, el día del examen se va a dar cuenta de la utilidad. No, me voy ...entonces salgo de ahí y me encuentro con una mujer, una historia muy larga, entonces la veo llorando, pensé que era una paciente y me di cuenta que era una colega que conocía lejanamente y que venía a escucharlo a Pichon y como el curso era en la sala cátedra, pensó que Pichon hablaba ahí, no, Pichon hablaba en otro lugar. De Pichón conocía solamente los trabajos sobre el conde de Lautreamont en el suplemento cultural de La Nación y me fascinaba lo que decía pero me parecía que era medio diabólico. Medio campesino estaba yo mirándolo, entonces me dice: -mirá Pichón tiene que dar una charla; -Ah, sí!, mirá, está en el otro lado; tengo el coche, te llevo. Era al otro lado del hospicio y Pichón estaba hablando sobre la psicosis y sobre la enfermedad única, era un delirio de Pichon esto de la enfermedad única; era su delirio no? Yo le decía: vos querés ser hijo único ¿no? Entonces había un pizarrón como este, Pichon tenía una apoyatura, decía una frase y trazaba. Yo decía que trazaba el lomo del bisonte en las cuevas de Altamira, hacía una cosa así, quería decir algo, consignaba algo, a lo mejor la espiral dialéctica, pero le quedaba nada más que un cachito de espiral. Después hablaba de la enfermedad única y ponía E-U, pero le había sacado la patita de la E y yo veo fascinado F-U, Fernando Ulloa, quedé fascinado porque realmente tuve la primera consciencia de lo que era el inconsciente con esa vivencia. Cuando termina le digo: -Mire doctor yo lo conozco a usted, conozco su trabajo sobre Lautreamont pero yo quiero ser analista así que... Ya había conocido a Freud hace años, aquí ya era médico, a Freud lo había conocido en Stefan Zweig o en el libro de Thomas Mann, pero me doy cuenta que no es diabólico es solamente mefistofélico, le causó gracia ... al Fausto. Entonces tuve tres entrevistas, a la tercera entrevista Pichon me dice que no me convenía. En la segunda me hizo una interpretación, la única interpretación que me hizo en la vida y fue la primera, él tenía la manía de cambiar de lugar lo muebles, la primera vez, quince días antes, yo me siento en el lugar donde me indicó y la segunda vez había cambiado los muebles y me siento en su sillón; era el mismo lugar... Él me dice, todavía no. Propiciatorio. Entonces la tercera me convence, él decía que tenía un costado muy parecido a él, que no nos convenía ni a él ni a mí, que estudiara con él pero que me analizara con otra 
persona. Le llevó bastante tiempo convencerme, cosa que tenía razón, entonces yo ya estaba viendo pacientes y asistía a los pasaje de sala en las salas de Méndez Mosquera, había visto pacientes que mostraba el recorrido, y entonces de golpe dice: caramba, me mandan una persona que ha tenido un accidente culposo -me dice- hace muchos años se murió la mujer, se murió la hija, el hijo se salvó; me cuenta un poco la historia que le habían contado, me dijo que se lo mandaban, que ese chico se recibía de médico ahora y no lo invitó a la recepción, que se casaba y no lo invitó al casamiento porque se había quedado con la familia de la madre y realmente había sido un accidente realmente culposo de él. A este hombre le habían quemado el cerebro con electro shock y era un sanitarista militar que ya estaba retirado hacía mucho, entonces le iban a hacer una lobotomía. Entonces Fabre que había sido compañero de Pichon y que era el jefe de psiquiatría militar, estoy hablando del 53, le dice bueno mirá ¿a ver si el psicoanálisis lo puede salvar? Entonces el paciente entra, ha estado esperando 1 hora y vomita arriba de la moquet, algunos ya conocen la historia pero fue una historia importante para mí, vomita. Pichon no se inmuta, dice: mire, tantas cosas usted que tiene que decir, no sabe toda la cantidad de cosas que me ha dicho, y yo todavía lo hice esperar, tanto tiempo que a usted nadie lo escuchó. Vamos a otra parte del consultorio. Para mí fue ya una lección. Algo hecho con humor, con un humor, cuando el humor está corrido hacia la crueldad es ironía cruel, es otra cosa, es lo que hacían los tebanos en Tebas cuando Edipo decía que iba a castigar a quien había matado al rey, y todo el mundo sabía que lo había matado él. Entonces los tebanos dice... este boludo va a castigar al que mató al rey y es él el que lo mató. Esto está más cerca de la ironía cruel. Pichon no era cruel aunque hay alguna anécdota que podía parecer medio cruel. Entonces resulta que el paciente cuenta sus cosas y dice, yo me doy cuenta que el hijo se recibió de médico y no lo invitó, se casa y no lo invita, él hace otro brote, está muy... es ahí donde deciden... sufría terriblemente este hombre y una melancolía... entonces... donde la sombra del objeto había caído sobre el yo realmente. Entonces yo digo ¿pero usted es el padre de Fulano de Tal? Era alguien que siendo yo docente ayudante había sido alumno este muchacho. Entonces Pichon dice: sí, es el padre de Fulano. Pichon... yo lo conocía solamente de la Facultad, me había recibido hacía tres años. Pichon dice, mire no sé si el psicoanálisis va a salvarlo de una lobotomía, pero el Dr. Ulloa que todavía no ha empezado a formarse como analista, tiene buena formación psiquiátrica, tenía buena formación, estaba con Pereyra, con Goldemberg, había ese curso medio malo pero que servía, dice: El Dr. Ulloa que es un buen psiquiatra y que tiene muchísimo entusiasmo por el psicoanálisis. El entusiasmo transferencial que yo había visto EU era Fernando O. Ulloa. Él apostó por mí, fue muy propiciatorio y me dice: lo puede salvar alguien que esté muy interesado y que tenga formación psiquiátrica y que esté muy interesado por lo que es la indagación del inconsciente. Entonces el hombre dice: ¿usted es médico? Mire, le estoy diciendo que conozco a su hijo de la facultad. Porque si usted es médico, yo también soy médico, yo no voy a pagar honorarios porque los médicos no nos cobramos entre nosotros. Pichon dice: bueno yo voy a supervisar pero tampoco voy a cobrar. Entonces me dice -esto tiene que ver con el humor conjetural, el no creérselo del todo- me dice: mire Ulloa, el Dr. lo va a tomar a usted como un hijo, él anda buscando un hijo, no sea su hijo. No tiene ninguna importancia mientras usted no se lo crea, por más que va a tener... pero esa es la verdad del campo transferencial, esa situación que ocurre, que no es cierto, no hay que creérselo, no hay que creerse ser sujeto supuesto saber, pero esa es la verdad.

El humor conjetural, bueno todo esto que estoy diciendo es parte de esa contradicción que dice 'no siga las huellas...' es al mismo tiempo un consejo de libertad y una orden. Pero entre 
eso nos manejamos, siempre la libertad esta restringida para que no sea delirio. Está restringida, es la libertad del malestar de la cultura. Escribí acá tensión dinámica, le pediría yo a él que me vaya escribiendo algunas cosas porque sino me voy a seguir dispersando. Es esa situación de libertad que después cuando hablemos de la tensión dinámica propia del malestar de la cultura y no del malestar hecho cultura que es la obra que en realidad escribió Freud, El malestar hecho cultura, se la puede reinterpretar por Malestar hecho cultura. Es una libertad restringida, vale decir que es lo que legitima la libertad en una convivencia democrática.

El humor conjetural es el resultado atravesado psicoanalíticamente, todo lo que pasa con un niño posterior al naufragio o a la derrota edípico. Ese chico empieza todo lo que Freud llamaba la novela familiar del neurótico y que yo prefiero llamar la novela familiar neurótica porque quién no es neurótico. Generalizando, no dejándolo para una neurosis grave. Todos tenemos. Entonces el chico ha descubierto, no conceptualmente sino que se le impuso después (posteriormente podrá ser un analista que lo conceptualice como lo voy a formular yo), ha descubierto que él no es causa del deseo de los mayores, sino consecuencia del deseo de los mayores. Esto sería realmente el derrumbe, cuando se pierde la condición de niño maravilloso, objeto del deseo, y es un hermano más, querido, no es causa, es consecuencia. Entonces ahí empieza el coraje de ese chico que para salir de ese padecimiento que a lo mejor, algunos con mayor o poco padecimiento, padecimiento siempre, algunos sumergidos en el síndrome de padecimiento, esta situación que después la vemos permanentemente cuando trabajamos en la marginación, síndrome de padecimiento de ese malestar hecho cultura, el tríptico que decía: la pérdida de coraje, la pérdida de lucidez. El sujeto no sabe a qué atenerse porque está acostumbrado, no sabe a qué atenerse y se atiene a las consecuencias. Lo que los griegos llamaban la posición del idiota. El desadueñamiento del cuerpo que no puede elegir acciones, acciones que conduzcan a una respuesta. Ese chico sale del padecimiento y con qué sale, sale con toda la fabulación, todos los personajes imaginarios, todos los juegos, dale que... Pero hay dos cosas.

Hay una cosa que me voy a olvidar. Después díganme: acuérdese lo que se olvidó.

Ese chico tiene, fabula toda la nobleza de la ficción donde no oculta los hechos. No oculta los hechos y termina resignificándolos. El chico está jugando en el recreo lo más bien y llega el momento del tiempo disciplinado y hay que ir a estudiar la tabla del 9 que es difícil, la del 7 es más difícil. Es un número cabalístico por eso es difícil la del 7.

Entonces si él (dá vuelta el cassette) esto ya empieza a ser el humor conjetural, cuando está incorporando la inventiva, está incorporando el placer. Lo contrario de eso sería la disposición obsesiva.

Un paciente, que viene hace un año, escribí hace poco un trabajo sobre el sacrificio encabezándolo con esto. Es un paciente italiano, muy inteligente que venía de Tierra del Fuego, más bruto que una reja de arado, que una pala mal manejada, pero muy inteligente. Entonces lo veo totalmente, con las venas hinchadas, hipertenso, aunque yo soy ex médico porque no tengo práctica clínica, tuve mucha práctica clínica, era obvio que este hombre era hipertenso, y le digo: pero usted es hipertenso. Y me da una respuesta realmente formidable, él tenía una concepción hidrodinámica o hemodinámica de la función eréctil, y decía, antes hipertenso que impotente. Él pensaba que por haber presión sanguínea... creo que me lo dijo medio en joda. Aquel sujeto que sacrifica todo placer en función de la eficacia. Trabajará, trabajará y trabajará y estará cavando su propia tumba y anula todo placer. Bueno, le digo yo: Usted debe ser muy eficaz en cuanto a la penetración sexual. Sus mujeres no deben de quejarse. Era obvio que la cosa era múltiple. Él me dice algo, también de antología, me lo dice en piamontés, yo voy a hacer un remedo del 
piamontés: Dopo que lei lo ha dito non a divinato súbito. Después que usted lo dijo lo he adivinado; se estaba burlando de mi. Dice, esa es la razón de la consulta, no tengo orgasmo. Vale decir que este sería un ejemplo del sujeto que no puede incorporar el humor conjetural, este era chistoso pero a qué grado, era cruelmente chistoso.

Bueno, hay otra cosa del humor conjetural, de esa novela familiar neurótica, de esa ficción, donde ya no es esa ficción que no oculta los hechos, es la ficción que oculta, enmascara los hechos, este es un ejemplo, entonces construye la nobleza de la ficción, lo llamo así por distinguirlo, no sé cómo llamarlo, de lo ficticio que es la construcción del fetiche. El fetiche es el único ídolo que se lo adora por lo que no es, es un bifronte, doble rostro de la mentira. La primera dice que está lo que no está. Lo sabemos los argentinos tantas veces. Un ejemplo más próximo era la ficción del 1 a 1, pertenecemos al primer mundo y toda la historia que esto significó, eso tarde o temprano se derrumba, ese rostro muere por sí mismo. El segundo rostro es difícil, es peligroso, el segundo rostro de la mentira fetichista que dice que no está lo que sí está, que no es posible lo que es posible, que esa es la derrota del padecimiento, la derrota de la mortificación. Este rostro es con el que nosotros trabajamos, ahí es donde viene la frase de Ortega y Gasset "no hay ninguna razón para no hacer lo que siendo necesario aparece como imposible", en este mismo salón yo hablé no hace mucho sobre el accionar piquetero -no voy a hablar de esto- equiparándolo con el accionar quijotesco. El escritor célebre, el príncipe de las letras más maltratado de la historia, es terrible, El Quijote no es nada más que la expresión, es casi el equivalente al corte de las rutas. Los piqueteros cortando las rutas están diciendo, interrumpiendo el tránsito en una especie de dramatización de la tragedia mayor de la miseria, en todas las rutas cortadas están haciendo, sin saberlo y sin proponérselo, están haciendo una dramatización de la tragedia mayor. El Quijote es una dramatización bastante grotesca por momentos, bastante dura, bastante cruel, de lo que fue la vida de Cervantes. Ese Cervantes horas antes de morir se despide de sus lectores y sus mecenas en la pobreza diciendo: el tiempo es breve, las ansias crecen, las esperanzas menguan, pero llevo la vida sobre las ganas que tengo de vivir. Esta situación es bastante importante, es fundamental porque es lo que puede tocar a alguien para salir de otra situación, que es el colmo del padecimiento. Y que precisamente también está referida al Quijote -no pensaba que iba a hablar de esto-, Cervantes hizo hablar al Quijote, hizo hablar al Sancho Pueblo -como lo llama Blas de Otero- que era el hombre sensato, la dupla con la utopía del Quijote con la sensatez de Sancho es lo que da fuerza a esta obra. Entonces también los hace hablar a muchos críticos literarios, me esta haciendo hablar a mí. Y Harold Bloom, que es un crítico literario que prologa la última versión del inglés -que me parece extraordinaria- de Edith Groisman, dice Harold Bloom hablando del caballero: "El caballero se disponía a luchar contra toda injusticia, la muerte, la mayor injusticia, esa última tortura". Claro la muerte de una persona indigente, la muerte ya instalada en la miseria, la muerte ya instalada donde el cadáver se presentifica ya, la muerte que está rodeada de la mortandad infantil, de la mortandad de viejos, si es que llegan a viejos. La muerte en esas condiciones en efecto es una tremenda injusticia, es una tremenda crueldad, es un tormento, es una tortura, no es la dialéctica de la vida y de la muerte. Entonces esto es lo que dice cuando esa situación que es el saber irrecusable que tiene una persona de síndrome de padecimiento. No necesariamente yo estoy pensando en el trabajo en la miseria, estoy pensando en el trabajo cotidiano. Vivo en Palermo chico, un lugar bastante confortable, veo pacientes de toda naturaleza ahí, pero también de todos los niveles sociales el sufrimiento este puede ser igual sobre todo cuando se instaura encerronas trágicas manicomiales, en la escuela, en el trabajo, en todos los lugares. También tengo el placer de trabajar con la 
gente de Oliveros y aquella vieja consigna 'hay que vaciar los manicomios' es imposible, no hay que llenarlos. Hay que tratar precisamente de resolver la situación antes.

Toda situación manicomial es una encerrona que podría responder a esto, esta última injusticia, o esta injusticia tal vez, no de morir sino de vivir así. Ese tormento de vivir así.

Me acordé de lo que quería decir. Otra cosa que es muy importante para el humor conjetural en ese atravesamiento de la novela familiar con el análisis. Freud dice que en la novela familiar todos nosotros tomamos los rasgos que más queremos de nuestros padres, o de personajes ideales, y con ellos construimos... no es que no tenga que ver con los padres, es a partir de los padres reales, buenos o malos, va más allá. Esto es la posibilidad de inventiva que va construyendo un chico después de esas derrotas del naufragio edípico y la derrota cotidiana de estar viviendo una situación tal vez arbitraria todos los días. Ahora, en mi propia experiencia de análisis, y como analista, no solamente como analizante, hay un detalle que siempre pesque y me conmovió. Me voy a permitir acá una pequeña situación con mi padre.

Mi padre era un inmigrante muy especial. Era de una familia económicamente buena, sin embargo emigró a los 15 años de Europa mandado por la familia, tal vez como se mandaba por alguna circunstancia. El padre de él había matado a un hombre en una riña, estaba preso, era una riña justa, es decir era una riña en defensa, pero yo nunca me enteré de eso. Yo sabía que mi padre, se transformó seguramente, eso lo averigüé mucho después, lo único que voy a contar es lo que él contaba, hablaba muy poco, muy poco de su historia, de su sufrimiento. Él se transformó en un muchacho rebelde, petardista, era medio... eran karlistas - socialistas, cosa curiosa, antiborbones. Estamos hablando de fines del siglo 19, 1890 por ahí. Entonces lo mandaron, tenía un familiar acá, unos tíos muy bien acomodados, lo mandaron por un año. Él eludió a los tíos, se sintió totalmente desacreditado en su lucha por reivindicar a su padre, seguramente ese es el significado, y entonces los eludió en el puerto, se fue a Constitución que recién estaba siendo una estación de trenes, sacó un boleto, no sé cómo habrá hecho, un boleto hasta fin de rieles. Es decir las vías que estaban construyendo Buenos Aires-Bahía Blanca, fin de rieles a mitad de camino, 600 kilómetros, en medio de La Pampa, se baja y hay un pueblito, un pequeño caserío en esa estación y hay un almacén, El español. Por supuesto era un significante donde buscó protección. Esta es la historia que a mí me conmueve. Entonces el español le dice: Muchacho yo no necesito empleado, acá lo atendemos mi familia. Pero no te puedo dejar tampoco en estas condiciones, casi sos un niño, 15 años recién cumplidos. Te puedo dar casa y comida hasta que consigas un trabajo, no hay cama todavía, vas a tener que dormir arriba del mostrador pero pronto habilitaremos una cama. Pero, me parece que tú nunca has trabajado. En efecto, nunca había trabajado, era petardista nada más. Tenía buena educación, había hecho casi lo que se llamaba el Liceo, casi un secundario avanzado, en los comienzos del secundario. Y le da una escoba. Claro nunca había barrido de mocoso. Entonces se pone a barrer el almacén, se le caen unos lagrimones, ¡caramba América era otra cosa! ¿no? Seguramente que también el hecho doméstico de estar barriendo ya estaba creando una condición distinta. El hecho de agarrar la escoba es un hecho doméstico. Algo lo empezaba a amparar. Entonces hace un delirio, un delirio maravilloso. Coño, dice - era muy mal hablado el viejo de chico- yo no estoy barriendo este piso tan sucio, estoy barriendo un fragmento del planeta. Y empezó a reírse.

La palabra fragmento es muy importante. Vale decir... ahí empezó su vida, yo no me vuelvo nunca más a Europa, me quedo acá. Se hizo amigo del telegrafista de la estación que era español, entró en Ferrocarriles, la historia sigue.

Porqué traigo esta historia. Porque mi padre era una persona socialista, tuve la catástrofe 
de la muerte de ese hijo que lo quebró mucho. No se quebró como hombre, pero se quebró muchísimo, se sintió responsable de esa situación aunque no lo era. Lo que toma un chico es aquellas cosas de los padres que no fueron, lo que toma para construir esos personajes; no es lo que le gusta solamente. Son aquellos proyectos, aquellos anhelos que quedaron frustro, que no pudieron ser pero que titilan en el rostro, titilan en palabras, titilan en los gestos; están presentes, es como si tomaran la posta. Cuando uno tiene la suerte de tener cierta cosa propiciatoria toma esa posta, y construye su fantasía, construye algo conjetural. Construye no mitos, va construyendo... Entonces desde esa perspectiva el atravesamiento analítico, lo dijo muy claro eso, al grado que tiempo después pude reconstruir toda la historia, me recorrí toda España, reconstruí toda la historia de mi padre. Recorrí Ceuta donde había estado preso y donde murió mi abuelo. Reconstruí la casa que había hecho el padre de él, del abuelo. Bueno empecé a reconstruir toda esa historia, me encontré con familiares y todas esas cosas que hacemos los analistas que estamos tratando de ver, somos analistas y somos de una manera determinada. Por qué subimos a este tren que puede ser para bien o para mal, cómo nos subimos, dónde nos subimos. Puede ser que fue como aquel muchacho campesino que la manifestación, pero empieza antes para un analista, empieza precisamente cuando la frase de Bascho, 'no sigan las huellas de los antiguos, busquen lo que ellos buscaron', la palabra antiguos remite no solamente a los antiguos, a Freud, a Klein, a Lacan, y otros antiguos que tenemos; para mí Thomas Mann, Stefan Zweig, mis padres. Los antiguos es la antigüedad de uno. Esa antigüedad de la novela familiar neurótica que no solamente termina ahí. Esto que voy a decir lo voy a decir nada más porque no es solamente como respuesta posterior al naufragio edípico, también es muy importante poder revisar, acá viene lo de conjetural, poder revisar aquello que quedó sumergido en ese naufragio. Quedó sumergido porque nunca fue memoria, porque son esas primerísimas vivencia que le pasaron a un chico que a los tres meses lloraba, lloraba y lloraba y la madre se enojaba incluso porque no la dejaba dormir, porque no sabía qué demonios hacer; hasta que viene una abuela o una vecina y le dice, pero escuchame tu chico está cada vez más flaco, y ahí descubre que en realidad o tiene muy poca leche, o tiene una leche no nutricia, cualquier cosa, y ese hambre que pasó esos 15 días ese chico, eso queda impreso. Nunca va a poder ser memoria porque no hay aparato psíquico todavía para que sea memoria, pero queda inscripto. Esa primerísimo experiencia, muchísimas experiencias que nunca van a ser memoria. Van a ir constituyendo... son habitantes de la represión primaria. No voy a hablar de esto, pero son habitantes importantes. Lo menciono nada más

Entonces cuando uno está hablando al azar de la memoria y sus vicisitudes, como estoy hablando y de golpe estoy hablando de cosas mías, estoy hablando de cuando me subí al tren. Yo no pensaba hablar de esto. Pero Liliana Baños me dice, lo vamos a escuchar por su ética, y entonces eso puede ser un halago, no lo crea demasiado, pero es cierto que también uno va, que el oficio es una manera de vivir. La ética también es una manera de vivir. Entonces no quiero desmentir eso porque si lo desmiento sería una mentira. No quiere decir tampoco que sea un campeón de la ética. La ética es un intento. Nos descubrimos en tantas trampas cotidianas, en tantas actitudes no éticas diría.

Entonces resulta que cuando uno está hablando así a la numerosidad social, muchos de ustedes saben porque es un concepto que yo manejo. Pero después quiero hablar de eso, o cuando uno está hablando en los recintos perelaborativos, es una forma virtual donde yo trabajo no ya en una situación ocasional como esta, aunque últimamente va siendo menos ocasional porque cada tanto estoy hablando acá, y creo que es la $3^{\circ}$ o $4^{\circ}$ vez; pero sí trabajo con un equipo en Berisso, de residencia integral donde hay 25 médicos generalistas, 11 trabajadores sociales, 9 
psicoterapeutas que son los que hay en esa residencia, y ahí trabajo todos los meses y trabajo un sábado por mes toda la mañana tratando de conceptualizar la práctica. Esa clínica a la que yo estaba aludiendo antes es una clínica que no practica teorías, no predica teorías, sino que las teorías -bienvenida la teoría y la excelencia teórica si uno la puede tener- son como restos diurnos que permiten ensoñar lo que está ocurriendo, lo que está aconteciendo ahí, ensoñar la práctica en una praxis. La práctica clínica es trabajar. Procesar, los datos de un campo, trasmutarlos, que los datos del campo estimulen el pensamiento teórico de uno, no que la teoría se imprima sobre el campo. Este punto es básico en sí. Busquen lo que ellos buscaron o lo que uno quiere buscar, porque busquen lo que ellos buscaron deja por fuera la crueldad. Porqué el psicoanálisis no buscaba la crueldad, hay muy pocos trabajos. Incluso hay bastante resistencia cuando hablo, este es un libro que estoy escribiendo y lo quiero, por ahí se va a demorar la escritura de ese libro, quiero poner todo lo que pueda poner, lo mejor que pueda poner en ese libro. A los 80 años casi lo veo como testamento. Testamento la crueldad, no, testamento la respuesta a la crueldad; el humor conjetural es una respuesta.

Ahora me perdí, me puse sentimental, uno habla de los 80 años y se pone sentimental...

Decía que cuando yo trabajo en los recintos perelaborativos que son dos cosas, primero es aquel lugar donde la gente se conoce cara a cara, perceptor y percibido. Vale decir que esas 40 personas con las que trabajo una vez por mes todo un sábado y conceptualizando la práctica de ellos, haciendo una capacitación no solamente sobre lo que está aconteciendo, sino haciendo praxis. ¿Qué quiere decir praxis? Praxis, la frase la explica Lacan, la praxis es trabajar lo real, lo real de la crueldad, lo real de la muerte, lo real de la miseria, eso que es tan difícil de ser simbolizado, intentar trabajar desde lo simbólico. Uno no puede atravesar lo real, pero no tiene que expulsar de su campo de percepción. Entonces qué trabajar. Empieza a crear nuevas realidades, empieza a ingeniárselas para crear bolsones del oficio cuando esta gente no está sostenida por un hospital de mediana complejidad, entonces hay que jugarse al equipo, crear bolsones del oficio. En estos bolsones del oficio que puedan tener cierta chance de no claudicar y hacer oficio, oficio clínico, oficio organizativo de la miseria, trascender el síndrome de padecimiento en cierta pasión, primero con ellos. En cierta pasión que vaya sublimándose como oficio, cómo se sublima una pasión como oficio? Hay algo que yo planteo siempre y también forma parte del humor conjetural, es las tres maneras de estar afectado. Cuando uno es clínico en situaciones difíciles que pueden ser estas que estoy describiendo pero que puede ser ese paciente o esa paciente atravesado por la pasión del odio, o atravesado por la pasión erótica, uno tiene que tener cierta simpatía porque sabe que eso es, esa pasión del odio ético - odio odioso. Entonces hay tres maneras de estar afectado que para mi van haciendo de la pasión oficio, en cualquier sentido. Primero es estar afectado en el sentido vocacional, ser afecto; ese muchacho que a los 14 años fue afecto a una manera de vivir. Fue afecto que lo llevó a ser maquí, a caer preso, correr riesgos, a intentar ser coherente y salvarse o morir coherentemente. Ese torturado que no denuncia porque está totalmente apoyado no solamente en la solidaridad con sus compañeros que no va a denunciar, sino también en un futuro en el que cree. Un futuro tal vez utópico pero en el que cree. Con esto no voy haciendo la vanagloria, o ensalzamiento, o la condena del que se quebró en tortura. Nadie puede decir que no se va a quebrar en tortura. Esto lo digo, me ha llevado algunos contratiempos con gente que ha pasado por esta situación y ha salido bien, no hay que idealizar la situación; las víctimas peores que yo he visto de la represión integral son personas que salieron 4 o 5 años después que se estableció el gobierno constitucional. Recuerdo uno, ni el nombre me decía; me pedía hora y me contaba cómo había estado preso, que había 
sido un error, que él había llamado a un amigo y que ese amigo se había olvidado de la consigna. Eran dos teléfonos que podía llamar. Él llamó a uno para citarse, donde ya de antemano habían acordado que si lo llamaba a ese teléfono era un llamado peligroso que no tenia que aceptar, y parece que este hombre fue entregado... ni siquiera tiene... es decir, está tan quebrado que preguntarle cómo se salvo ya es un interrogatorio torturante. Estas son las peores víctimas. No puedo tener simpatía por el que se quebró, pero no puedo dejar de mirar el sufrimiento de estas personas con empatía. No sé qué me pasaría a mí en esa situación. Esta situación la he discutido mucho y son víctimas, los que más han pagado, ni siquiera tuvieron la suerte de morir en la situación. Su vida es un tormento.

Entonces, dos cosas nada más y me pongo a leer esto. En esos recintos perelaborativos donde el recinto no está dado por las paredes, está dado por lo que no se puede decir ahí adentro, por las cosas que se dicen afuera, porque ser clínico en esas condiciones significa tres cosas, que uno -que me toca a mí también aunque sea asesor o este trabajando ahí, pero me toca tambiénque uno toma una medida correcta, a lo mejor consensuada, que uno tiene un ancho margen de duda si eso fue correcto o incorrecto, si ese era el antibiótico, si tendría que haber quedado o no internado, si tendría que haber enfatizado más el diagnóstico, si la chiquita... era realmente era realmente una falta de higiene que venía con un flujo mal oliente y con excoriaciones en la vulva o era realmente un abuso violento, un abuso deshonesto, abuso sexual. Entonces uno se queda en dudas. Pero con mucha frecuencia descubre que aquello que pareció correcto fue un error, un grosero error que incluso es atribuible a un déficit personal de uno, aunque sea consensuado, que algo se le escapó, que se distrajo, y entonces como no saben que esas son las leyes para ser clínico en esas condiciones con ningún sostén cuando todavía no se ha formado un equipo, un bolsón del oficio, con esas que se dicen ahí hay que ir creando condiciones para que eso aparezca ahí y para que la persona que esté incluida en esa situación de fracaso no sea escrachado como un miserable, no se haga la vista gorda, pero ese el precio que se paga entonces se van creando condiciones donde lo que se dice afuera, es decir lo que queda en los recintos de cada uno, empieza a decirse ahí. Ese dispositivo cuando uno está trabajando con la numerosidad social, la numerosidad social es que yo en este momento me dirijo en todo momento no a una masa, me dirijo a cada sujeto que está escuchando. Pero no es que yo me dirija arrogantemente en una situación de (...) estoy apostando a lo que le va a pasar a cada uno. ¿Qué le va a pasar a cada uno?. Bueno, algunas cosas las escuchó y se aburre; otras cosas son nuevas; otras lo tocan, lo conmueven. Algunas cosas provocan ese saber perelaborativo donde uno puede decir fugazmente 'me doy cuenta que siempre supe algo de lo que acabo de saber'. ¿Por qué? Porque algo de lo que fue reprimido en el naufragio edípico, pero que fue memoria, fugazmente... El ejemplo paradigmático es cuando una frase como esta de Bascho y uno quisiera haberla escrito a esa frase y resiste a la tentación plagiaria; y dice esto lo leí en tal lugar pero esa frase estaba escrita en uno. Pegó en una cosa que tal vez no estaba formulada así, pero pegó en algo que era memoria, memoria reprimida o memoria olvidada.

Esto es bastante importante cuando yo estoy hablando a tantos sujetos como sujetos hay acá, pero además no son sujetos aislados, uno trata de eludir los fenómenos de masificación. Entonces no son sujetos aislados, son sujetos contextuados que hacen malestar de la cultura. Acá viene lo de tensión dinámica. Malestar de la Cultura; Freud escribió sus tres últimos trabajos ya en la última década de su vida que es El porvenir de una ilusión, El malestar de la cultura y El porqué de la guerra y el diálogo con Einstein. Él dice una cosa curiosa. En el 25 él había hecho una presentación autobiográfica, creo que era para la enciclopedia británica, no sé si se 
publicó, creo que no, pero él hace un agregado, una addenda a esa presentación autobiográfica y dice que él se ha encontrado tardíamente con sus amores juveniles por la cultura. Entonces escribe esos tres trabajos.

Después dice que él observa, no hace ninguna aclaración, que ha cambiado significativamente su estilo de escritura teórica. No aclara nada pero después agrega que esos trabajos, para los que trabajamos en el campo social son importantes, no tienen ningún valor psicoanalítico. Que cualquiera los podría haber escrito. Ahora, intrigado por esto empecé a conjeturar qué podría pasar, volví a leer estos trabajos y me di cuenta de lo siguiente. Me dí cuenta que él ha cambiado de estilo. Ha abandonado el estilo de la narración que es un estilo propio, yo estoy haciendo narración acá, estoy tratando de llegar a ustedes, estoy tratando al mismo tiempo que hablo me van sucediendo algunas cosas, tengo cierto registro de lo que me sucede, pero cuando uno está haciendo un historial clínico, no historia clínica, en la historia clínica se trata de consignar, relatar, referir, lo más ajustadamente posible lo que pasó en esa historia clínica, sea cual fuere la historia clínica de un cirujano, de un analista, sea una historia clínica de un psicólogo que está haciendo clínica médica en el sentido de ajustarse -no porque sea médico- se está ajustando a los hechos tal cual ocurren. Cuando digo clínica de linaje médico también digo clínica de linaje psicoanalítico como dos clínicas que no son diseños puros, son diseños que permanentemente se nos mezclan permanentemente cuando están haciendo una cosa u otra, sea el psicoanalista más psicoanalista o el cirujano más cirujano atendiendo el paciente. El historial clínico es una narración, es una intervención directa que uno está haciendo. Cuando uno trabaja en el campo social -Freud no trabajó en el campo social, no intentó trabajar y no le daban los años- todas las vicisitudes que significan pretender sostenerse como psicoanalista en el campo social, donde uno es convocado, pero no demandado como analista, a lo mejor tolerado solamente. ¿y cómo se las ingenia uno para ser pertinentemente analista que está atendiendo no solamente el objeto abstracto, el objeto teórico del psicoanálisis que es inconsciente también esta atendiendo en la conciencia. ¿Por qué? Porque trabajando en esa residencia integrada yo puedo estar capacitando a la gente recuperando lo que está pasando, pero estoy haciendo praxis tratando de crear nuevas realidades que engarcen lo real, nuevas realidades, nuevas subjetividades para poder seguir teniendo cierta chance de hacer lo imposible y en esas condiciones es que yo estoy operando sobre la gente, pero la gente no está operando sobre mi. En esas condiciones puede ser que en un momento dado no aparezca en alguno de ustedes, pero sobre todo ahí, -esto para mi es muy importante- no aparezca algo que uno dice 'me doy cuenta que siempre supe lo que acabo de saber', lo que se acaba de convocar en esa construcción que uno está haciendo mientras está haciendo conjeturas como cual podía ser la salida de algo imposible, está haciendo inventiva, está haciendo juegos en el mejor sentido, no está haciendo fetiches, no está diciendo que está lo que no está, ni tampoco que es imposible, no está lo que sí está, el intento de salir. En ese momento hay cosas que se convocan que nunca fueron memoria, se convoca lo que le pasó a ese chico de tres meses que pasó hambre, lo que pasó a ese chico que nació y se encontró con una luz que lo impresionó cuando acaba de nacer y todavía alguien le va sacar una foto en la cara y lo encandila con el flash. Todo lo que son experiencia, la misma experiencia de parto, esas nunca van a ser memoria, pero están contenidas. Entonces ¿qué pasa? Esas cosas pueden ser convocadas, no tocan la memoria, tocan el ánimo y de acuerdo a la procedencia, lo pueden tocar fastidiosamente o lo pueden tocar entusiastamente porque de las dos cosas existen experiencias de gratificación y experiencias de frustración. Esto es fundamental cuando uno está tratando de llevar adelante un equipo que está trabajando en condiciones muy deficientes, como se le toca 
el ánimo, como se le da lugar al fastidio estar trabajando en eso, se le da lugar al odio, se le da lugar al sufrimiento y se le da lugar también a la gratificación.

Entonces todo eso que toma lo previo al naufragio y que toma eso que se llama la novela familiar, todo eso es lo que forma el humor conjetural. El humor conjetural -ahora lo digo- es una adquisición autobiográfica, como era en este hombre del tren cuando dijo voy a ser coherente (...) sobre este tren, es una adquisición autobiográfica que en la capacitación cotidiana, Pichón diciendo yo enseño análisis básico y lo que la vida le va enseñando a uno lo va analizando. Es una adquisición autobiográfica que es una disposición, yo hace mucho tiempo que no hablo de dispositivos ni de encuadres, hablo de disposición. La disposición es una actitud con que uno se para clínicamente frente a un campo pertinentemente a las condiciones de ese campo, es un actitud como disposición a la acción y que está totalmente engarzada con otra palabra casi eufónica de actitud que es aptitud, viene de apto, de idoneidad, cuando una persona tiene una determinada disposición como adquisición autobiográfica adquirida que se va perfeccionando que no es cristalizada, si yo dijera cuando uno tiene un precipitado autobiográfico, ahí posiblemente hay una cristalización y el sujeto no sigue más adelante en su capacitación, se refugió en ese valuarte. Ahora cuando uno tiene una buena disposición la aptitud, la idoneidad, es mucho mayor, pero cuando uno tiene una capacitación, una buena idoneidad científica, una buena idoneidad teórica, también es mucho más fácil la disposición en función de otra, esto para mí es lo que llamo humor conjetural.

¿Por qué lo llamo el humor conjetural? Porque es una forma de ser, porque es un talante. Humor no solamente está ligado al humorismo, puede haber un humor del carajo. Yo suelo hablar del humor del carajo cuando uno es un dolor enojado sobre un trasfondo de impotencia donde no se encuentra salida, es el paradigma de la mortificación del síndrome de padecimiento donde se ha perdido valentía; donde se ha perdido lucidez e inteligencia y donde se ha perdido contentamiento. Vale decir, si hay algo que es un trípode que niega la salud mental, finalmente la salud mental es coraje, es valentía, es lucidez, es contentamiento en la acción, eso que emana del cuerpo donde el desgano se vence y donde uno va contento a un destino. Yo venía contento hoy acá. Me acosté a las 2 de la mañana, y manejaba 300 y pico de kilómetros y cuando me pregunta alguien le digo: mirá vine preparando la charla. Me iba divirtiendo con la charla. Me dí cuenta que más o menos que la terminé a los 283 kilómetros. Era 283 que me marcaba... el chornaleto este, lo que marca desde que salí de Bs. As, estaría a 20 kilómetros de acá. Entonces a los 280 me avisan... y paro.

Quería decir algo más conjetural. Esta es la palabra. Todo está bien, el talante, lo contrario del humor del carajo, además es humor colectivo, es una cultura que se va creando ahí para hacer camaradería, para hacer malestar, la tensión dinámica del malestar de la cultura y no del malestar hecho cultura, que fue lo que escribió Freud en realidad. Yo decía que descubrí que Freud, enseguida voy a conjetura y termino ya, voy a leer esto, que Freud había abandonado la narración y se había dispuesto, y esto es formidable, se había dispuesto a negarse a aceptar todo lo que niega la realidad de los hechos, una doble negación con valor afirmativo. Él hace un diagnóstico tremendamente pesimista sobre la cultura de la humanidad. En realidad lo que él ha descrito, claro en 1937, bueno todavía estaba en Viena, por primera vez se descubren células cancerosas. Él nunca tuvo un cáncer, era una enfermedad iatrogénica, tenía un pólipo florido, lo radiaron, lo radió, eso fue una cosa curiosa de Freud, lo radió un paciente de él, lo precario de las máquinas de radiación de esa época, tenía los dedos amputados por las radiaciones, él fue el que lo radió. 
Un médico argentino, trabajó con todos los tacos, las diferentes biopsias y solamente al final, los últimos tacos, tienen células pre cancerosas. Nunca fue un cáncer. Algo curioso ¿qué pasó ahí con Freud? No hay que justificar la pulsión de muerte en esto, creo que tiene otra dignidad la conceptualización, pero no es ajeno a esto. Él escribe este malestar de la cultura en la última década de su vida, pero poco antes de morir un periodista le hace una entrevista y le dice -una entrevista no muy memorable, pero Freud dice: no me tome por un hombre pesimista, yo no soy un hombre pesimista; yo soy un hombre que se atreve a hacer diagnósticos todo lo pesimista que sean porque no solamente en eso se puede fundar el optimismo, en no negar cómo es la realidad. En no negar la crueldad de los hechos, lo duro de los hechos. Entonces Freud abandona la narración, y esto es otro recuerdo infantil. La palabra no tiene casi etimología, y yo aprendí escuchando a mi padre, una palabra que la escuché dos o tres veces, narria. Narria es una palabra pre romana, posiblemente etrusca que pasa al vasco y del vasco pasa a algunas regiones de España. Después la cambié etimológicamente y quiere decir trineo y trajín, el trajín con que se empuja el trineo de una narración, el trajín con que yo estoy empujando el trineo de lo que estoy diciendo. Ahí se van montando seguramente muchas cosas. En ese grupo que es un grupo en ese recinto perelaborativo donde aparecen tantas cosas revisadas del hoy y del ayer de cada uno, en silencio, eso aparece en cada uno y no es pertinente meterlo con la prehistoria de cada uno ahí, y se va haciendo una narración solidaria. Entonces como Freud no le da ningún valor; fijense que paradoja, él había escrito las neurosis actuales antes, un concepto freudiano pre psicoanalítico, escrito antes que pusiera a punto el psicoanálisis, antes de lo que fue su propio análisis y su acontecer freudiano. No me meto con esto. Y la diferencia de la neurosis transferenciales, las neurosis actuales responden a causa concretas, casi requieren como la miseria, medidas políticas -él decía medidas higiénicas- hablaba de los trastornos libidinales de sus pacientes, pero los deja por fuera del análisis y en sus tres trabajos importantes simplemente los refiere, refiere con rigor los hechos, quedan también por fuera, quedan como neurosis actuales.

No hay ningún futuro para la humanidad, según Freud. Freud no trabajó, no hizo narración porque no trabajó concretamente en el campo concreto. Tampoco se lo podemos pedir. Los que trabajamos concretamente sabemos que es cierto lo que plantea Freud, pero que vale la pena intentarlo, que tal vez no podemos lograr un destino distinto de la humanidad. Las guerras siguen siendo guerras, las cosas que pasan en este momento son terribles, las cosas de donde venimos, las cosas a donde vamos, pero eso no quiere decir que esos recintos perelaborativos, son recintos donde la gente se percibe y se percibe, donde circula la palabra, donde es previsible encontrarse, por eso son tan importantes los partidos políticos, los que muchas veces denigramos, incluso las minorías políticas que pueden tener cierta situación de recinto cuando no se encausan como guetos donde esas paredes permeables también tienen que ser para afuera, donde se está procesando algo. Por eso es importante trabajar, para mí en Berisso, trabajar en la Colonia Oliveros, estar hablando con ustedes, aunque esto sea nada más que episódico.

Yo sé que tengo algo que decir pero no me acuerdo qué es. Estoy haciendo tiempo para hacer un remate... ah!! Conjetural.

(Cambia de cassette)

Conjetural viene de eyección, de expulsado, de ahí viene la palabra conjetural, pero tiene las variables que tiene. Si la eyección es hacia abajo puede ser deyección, mierda por la palabra, a veces nos mandamos grandes cagadas, deyección. Excrementos. También puede ser abyección, abyecto, bajeza. Nos encontramos permanentemente con bajeza, pero también es proyecto que ya solamente es a futuro y también para arriba. Empieza a ennoblecerse la cosa. Es el proyecto 
conjetural cuando uno está tratando de establecer algunas situaciones desde un hoy, un hoy como acto clínico, acto político, como esta transmisión. Un hoy que uno trata de examinar el pasado o provocar cierta curiosidad, cierta emergencia de ese pasado en quien está escuchando. Para qué. Para salvar el futuro. Eso que dice Carlos Fuentes, el mejicano. Dice: "La memoria salva, filtra, escoge, pero no mata. No hay presente vivo con pasado muerto"; con pasado peso muerto. La memoria y el deseo salvan el futuro. Ese es el devenir. Lo que nosotros hacemos permanentemente es devenir.

Termino con esta palabra que quiero decir. Cuando uno reinterpreta el malestar de la cultura como título, como propuesta, entonces uno está trabajando con tantos sujetos como sujetos están ahí, sujetos que van por su propia antigüedad, por su propio camino y entonces en un momento dado nos encontramos en una situación difícil. La palabra teorizar se remonta a la tragedia griega, Eurípides, Esquilo, todos estos, Sófocles, todos estos que conmovían el alma de los griegos, los tocaba a cada uno en su propia singularidad, entonces iban al ágora y era un despelote, cada uno decía de lo que había visto en la escena trágica. Lo mismo hacemos nosotros después de una puesta teatral, de una película, después vamos al café, al bar, y cada uno dice según lo que le tocó y le tocó según le fue en la feria. Vale decir son dos o muchos que entienden. Es un momento importantísimo, yo no quiero enriquecer un campo con todo el saber y la subjetividad que hay ahí. El problema es cómo se crea luego un debate crítico o cómo cada uno va y escribe, hace su propio paper, después lo discute; cómo pasan del dos o muchos que entienden al dos o muchos que se entienden; a una comunidad organizada, a toda la fuerza de lo colectivo; a eso que muchas veces hay una calumnia sobre lo colectivo, se dice sobre las comisiones. Se dice que un camello es un caballo hecho por una comisión, chiste muy repetido. En realidad una comisión, un comité, un colectivo que esté bien afiatado tiene la experiencia de un veterano aunque sea novato. Es capaz de inventar un camello, no que le sale un camello. Es un camello que cruce del desierto en la intemperie o lo que sea.

Creo que tengo que terminar acá. Quiero leerles entonces, son 4 páginas, no son 5 páginas, digo que son cuatro para que... pero en realidad son 6 , no creo que son 9, este trabajo es lo que me va a permitir... si yo hubiera hablado de esto estaría hablando mañana todavía. Por eso fue largo, lo que dije la introducción de una actitud clínica que yo llamo humor conjetural como adquisición autobiográfica que es lo que permite soportar ciertas cosas.

A mi me permitió en el 2000, haciendo un peritaje terrible, un peritaje tipo donde había que contestar una pregunta del expediente, para Abuelas, una pregunta del expediente que decía, donde se estaba juzgando a Masera, a Videla, a los genocidas por crímenes contra la infancia, que no prescriben. El expediente era aludiendo a una nieta de las Abuelas que está todavía sin recuperar, decía ¿Qué le pasa a un niño no nacido, vale decir cuando la madre embarazada es secuestrada, torturada; una madre torturada es un niño torturado, mantenida en cautiverio hasta el nacimiento y muerta luego de nacido el chico y el chico entregado a expropiadores? Nos pasamos un año con Eva Giberti y Ricardo Rodulfo, expertos en infancia, tratando de..., peritaje tipo porque no hay pruebas, estás los supuestos, son hechos fehacientemente comprobados y están quienes han sido autores de esta situación, ideológicos o materiales. Vale decir que el juicio tiene un destino pero hay que hacer conjeturas. La clínica de la marginación y en la clínica cotidiana, y en la clínica médica hay muchísimos momentos como para poder hacer.

Yo me acuerdo que lo que me resultaba muy importante era cómo hacer que esta situación, tomando lo de Derridá que todavía no había leído, que es esta oscuridad para atravesar la crueldad no solamente la crueldad es una cosa cotidiana, convivimos con la crueldad que se 
transforma en lo cruel, lo neutro, convivimos permanentemente con lo cruel como un hecho cotidiano, latente. Cómo conmover, cómo llegar, entonces decidí que describí una, voy a llamarlo así aunque es medio ingenuo, describí una sala de partos tierna. En realidad la palabra tierna es una mala palabra para una buena calificación porque alude a lo tierno, recién nacido, en realidad la ternura es el buen trato o trato según arte; las donaciones materiales y las donaciones simbólicas del buen trato, de buen trato viene tratamiento y viene contrato, contrato social, contrato solidario.

Bueno, una sala de buen trato, donde están la madre, el padre, el partero, los abuelos afuera a lo mejor protestando, peleados con qué se yo porque no les avisaron, cualquier cosa, toda esa cosa que ocurre normalmente... lo más naturalmente sin idealización. Luego describí lo que era una sala de partos, fehacientemente comprobado el hecho, donde está la madre sola, están los carceleros, están los partero, los médicos que son los torturadores, está el mismo que le va a dar después una inyección de curar para matarla, está ya con destino ya... tal vez de alguno de ellos se va a apropiar de ese chico. Vale decir, confrontando ambas cosas era muy eficiente en ese telón de fondo del buen trato... No sé que va a pasar con eso pero lo tomó naciones Unidas el peritaje y lo tomó Garzón como peritaje tipo aplicable a otras situaciones, y ahí fue donde por primera vez se me hizo clara la crueldad como sustantivo, lo cruel realmente como cosa materializada, por eso dije que lo mismo le pasó a Freud cuando habló largamente de la pulsión de vida y en un momento dado aparece la pulsión de muerte. Entonces me dediqué a trabajar sobre la crueldad y dí 25 conferencias trabajando y conceptualizando, dí 30 y pico, tratando de crear debate, es una cosa que generalmente es muy difícil debatir, y bueno fui avanzando en esto. En el 2000, ya venía hacía 1 año y medio trabajando.

Entonces en Barcelona, "Para el propósito que anuncia el título -se llama La perspectiva metapsicológica de la crueldad- examinaré prevalentemente aquella forma de la crueldad que denomino, de manera algo paradojal y, que luego aclararé, vera crueldad o crueldad mayor. (Lo paradójico es vera que es veracidad). Tendré presente además otras formas mayores de esta patología; por ejemplo la del sobreviviente de condiciones extremas de marginación social. Algo semejante, pero menos frecuente, puede ocurrir con otro sobreviviente, no ya de la miseria económica, sino de un nefasto ámbito de familia donde priman los atrapamientos incestuosos o los arrasamientos despóticos. Ambos sobrevivientes lo son de condiciones "infamiliares", connotando el carácter siniestro (infamiliar quiere decir, en alemán unheimlich, quiere decir siniestro) que este término tiene en psicoanálisis. Tampoco dejaré de lado la forma más universal de la crueldad, enmascarada como "lo cruel". Una acostumbrada presencia hecha cultura con la que se convive, por momentos en connivencia, en el sentido de ojos cerrados e incluso guiño cómplice. Lo cruel, como producción sociocultural, se corresponde, en la estructura psíquica, con cierta predisposición universal hacia la propia crueldad en todo sujeto humano, sobre la que volveré al final.

La vera crueldad necesita de un dispositivo sociocultural, cuyo eje es la encerrona trágica; una situación de dos lugares, el victimario, protegido en su pretensión de impunidad, y la víctima desprotegida de todo auxilio. Falta la presencia eficaz de un tercero de apelación que desarme esa encerrona cuyo paradigma es la mesa de tortura pero con muchas otras formas de expresión en la estructura social, en que sus habitantes están impedidos de ser no sólo legítima hechura (termino hablando de la tensión dinámica), sino también protagónicos hacedores de la cultura. La tensión dinámica es cuando un sujeto es hechura legítima de esa cultura: eso es lo que se busca en el recinto. Vale decir, sacrifica parte de su libertad en función del bien común, 
sacrifica esa parte. Ese sacrificio de parte de la libertad es lo que impide que la libertad sea un delirio descontrolado, pero legitima que tenga la libertad también para ser al mismo tiempo hacedor protagónico de esa cultura. La tensión dinámica entre ser hechura y ser hacedor es el malestar de la cultura como un elemento que motoriza y que dinamiza cualquier proceso cultural no solamente de una cultura en términos de salud mental, sino en términos de una organización democrática de una sociedad. Salud mental y democracia en ese sentido están totalmente involucradas y también agredidas. Este malestar de la cultura es un buen caldo de cultivo para la reproducción de la crueldad.

Será útil hacer algunos comentarios previos para abordar, con mayor eficacia, el núcleo esencial metapsicológico de la crueldad mayor. Adelanto que éste gira entorno a una radical falla (en la crueldad) en el proceso psíquico de la represión, al parecer por causas anteriores a la que Freud conceptualizó como represión originaria y secundaria. Estoy proponiendo una proto-represión asentamiento de las otras dos. Me doy cuenta que es demasiado el cambio entre la narración que iba haciendo y lo que estoy leyendo. Entonces lo voy a hacer breve. El punto es este, el punto que quiero señalar.

En un escenario de la ternura, un escenario del buen trato, un infantil sujeto no solamente va recibiendo el abrigo para los rigores de la intemperie, el alimento para los rigores del hambre, sino todas las donaciones simbólicas. Porque un sujeto es inválido no solamente por su invalidez, es inválido porque no tiene ningún código. Cuando va recibiendo los códigos que le van permitiendo acceder a un lenguaje, porque el chico llora, la madre saber por qué llora el chico, es la empatía. Ese chico llora por hambre, por angustia y la madre saber por qué llora y logra que el justo suministro, ahí empieza a transformarse esto en un lenguaje. Es la génesis del lenguaje. Hellen Keller, que fue ciega sorda y muda, a los 6 años se la puso al cuidado de Miss. Sullivan y Hellen Keller que llegó a ser una pensadora bastante destacada, decía que su primer acto inteligente que recuerda fue cuando se dio cuenta que Miss Sullivan no apretaba, no presionaba un instante más que el necesario para que ella se contuviera. En ese momento dejaba de presionar. Ese fue el primer acto inteligente que le permitió luego llegar, a pesar de su invalidez, llegar a lo que llegó. Lo mismo pasa con un chico. ¿Qué ocurre? Esta es la parte medio complicada.

En estas condiciones del suministro de la ternura, el sujeto nace con un paquete instintivo muy precario, pero es muy precario, a $5 \mathrm{~cm}$. del pecho se muere del hambre si no lo pone la madre o si no lo alimenta, pero tiene todo el linaje filogenético desde el Big Bang en adelante. Tiene los que son los códigos para ser sujeto viable que han atravesado la evolución desde que el mundo es mundo. Entonces ese instinto es metonímico, cuando aparece en la evolución la sexuación, vale decir que ya no, el sujeto necesita de dos gametas; mejor dicho la vida necesita de dos gametas, masculino-femenino, para generar un nuevo sujeto, un nuevo prototipo con algunas modificación, se necesita el salto del instinto, vale decir el instinto que las ponga en contacto. Es el primer salto, el salto del instinto. El instinto es metonímico, vale decir que es una fuente en lo orgánico, tiene un solo destino, tiene un solo objeto. Hace millones de años que la avispa San Jorge, acá se llama San Jorge, busca una araña, le clava un aguijón, la deja paralizada, no la mata, desova y a los 7 días sus larvas tienen alimento. Siempre es lo mismo, no hay ningún aprendizaje, esto quiere decir que es metonímico, que no hay solución... Cuando el llanto de un chico es expresión, voy a llamarla diplomática, representación diplomática, enseguida van a entender porqué digo diplomática, tiene un poder que no está ahí, está en el soma. Vale decir ese poder que en el soma requiere alimento. Entonces el chico llora, se expresa, es expresión de un poder que está en otro lado. Llamamos entonces a eso representación diplomática en el 
sentido que es representación de algo que está en otro lado. Tomando una metáfora como una figura común.

Por otro lado en el campo de la representación, donde se encuentra esa madre frente a ese chico que llora, esa madre atravesada por la ternura como una producción cultural, la ternura es la demora, vamos a decir la coartación así lo digo en términos freudianos, yo digo la demora, del fin último de la pulsión. Yo decía, en el escenario de la ternura ni se sobre agrede ni se sobre excita a un chico.

¿Cómo se asume la ternura? La ternura se asume por lo que no se hace, cuando yo estoy frente a un grupo trabajando en la numerosidad social, no tal vez acá como alguien que está haciendo una disertación, sino trabajando realmente en esos recintos donde no he sido convocado como analista, he sido convocado pero no demandado, yo asumo teatralmente la representación de un analista. ¿Cómo la asumo teatralmente? La asumo por lo que no hago, no predico el psicoanálisis, no ocupo lugares vacantes porque el jefe de ese servicio es un nabo y entonces no me transforma en un poder paralelo, simplemente por lo que no hago asumo. Entonces es muy claro, si yo estoy representando a Hamlet, to be o not to be, Hola cómo te va!! Y saludo a alguien del público, se acabó la escena. No saludo, estoy en una situación desde lo que no hago. Entonces la ternura es un rol teatral en el sentido de que uno puede hacer muchas cosas desde lo que no hace. Cuando se encuentra esa expresión cultural que es la ternura, es una producción cultural también la crueldad como fracaso de la ternura - eso lo vamos a ver enseguida- también es una representación cultural, se encuentra con ese instinto metonímico. El instinto va mutando, se va transformando en ese misterio que se llama pulsión propia solamente de la vida inteligente, después voy a dar un ejemplo. Acordate que tengo que dar el ejemplo de los chimpancés.

¿Qué ocurre? Que se va viendo una mutación, eso que Freud decía: las pulsiones son nuestra mitología. Todavía creo que lo que estoy diciendo es una mitología, pero es una mitología que es menos mitología porque son observaciones clínicas, la ternura no la aprendí yo, la habré mamado de mi madre, pero no la aprendí. La aprendí como conceptualización trabajando en el campo paradojalmente de la crueldad y también de la ternura, trabajando clínicamente, trabajando el humor conjetural, el humor conjetural es exactamente una producción de la ternura, sofisticada, puesta al servicio de determinado oficio.

Eso metonímico del instinto va haciéndose precaria metáfora, la pulsión es precaria metáfora porque también tiene una fuente, el hambre también se siente, la pulsión sexual también se siente en el cuerpo, pero puede ir por aquí o puede ir por aquí, no tiene un solo camino. Ya es lo mismo pero de otra manera, y ya es lo mismo con este objeto o con este otro objeto, ya hay metáfora, ya es una producción cultural la pulsión; ya se va aprendiendo que esta madre me canta así y que esta tía me canta así, y que esta tía me canta de otra manera y que toda... va haciendo metáfora. Entonces cuando por el éxito del escenario la ternura, la crueldad está siempre presente, son dos producciones culturales contemporáneas y antitéticas desde la noche de los tiempos, al margen de que la crueldad sea un fracaso de la ternura. Eso me encamino a demostrar.

Cuando se logra un muy buen establecimiento pulsional, una actitud pulsional consistente, el cachorro animal recién nacido, recién venido se va haciendo sujeto humano, se va haciendo sujeto pulsional, camino a ser sujeto ético, si es que hay un buen establecimiento de la situación pulsional se aclara enseguida esto. Entonces tenemos esa situación, el instinto nunca es cruel, es agresivo, es agresivo porque está en la línea de la alimentación, y es agresivo porque está en la línea de la reproducción, vale decir dos circulaciones que hacen a la sobre vivencia de la especie y 
del sujeto, del individuo. Pero acuérdense que todo esto nació de dos gametas, femenina y masculina que tienen que encontrarse. Cuando se encuentran, se encuentran en la vida no humana, se encuentran por el salto del instinto. En la vida humana ya es por el salto pulsional, ya hay metáfora, algo de la cultura está operando en este sujeto, pero volvamos al instinto. Se encuentran estas dos gametas, se acoplan, hacen un nuevo sujeto, si tiene suerte otro sujeto, y afuera ... muere. La muerte, esto es de Serigido un investigador argentino que vive en Méjico. La muerte en este sentido es el gran acelerador de la evolución de la especie. Si no murieran los padres no habría evolución. La pulsión sería demorada. La muerte es lo que va creando sucesores con algunas modificaciones que podrán ser filogenéticos por Darwin, o será por Lamarck serán culturales. El deseo va cambiando. Entonces si hay un buen establecimiento pulsional, el tercer salto de la metáfora. Acuérdense, la pulsión es una pequeña, precaria, ya producción pulsional, precaria metáfora por un camino o por otro pero no por infinitos caminos, pero es un tercer salto que es el loquis, la palabra. Loquis mismo, loquis que es palabra, coloquio, circunloquio, locutorio, interlocutor, infinidad de variables de la palabra loquis. La palabra es el reino de la metáfora, es el reino de la cultura. La palabra pensada es lo que va haciendo la ley, cuando la ley va operando sobre la pulsión, la pulsión bien establecida ya ha hecho frontera con la agresión del instinto que al mismo tiempo está sostenida por la cultura, la agresión cada vez va siendo menor o la agresión va ocupando menor lugar, esa es la ilusión. Ahora cuando por fracaso de la ternura ha habido precario establecimiento pulsional, de esa instancia pulsional un precario establecimiento, de esa insinuación de la estructura casi biológica del sujeto de la cultura que además va siendo la instancia psíquica, no hablemos del aparato psíquico que es una entelequia teórica, va haciendo instancia psíquica la pulsión como bisagra sostenida por la cultura, va haciendo frontera con el instinto. Ahí entre el techo de la pulsión, ya que hablamos de salto, y el piso del instinto es donde yo ubico un tercer tiempo de la represión que es la proto represión. Decir proto no es decir que es primera o segunda, o primera en relación a la represión primaria o secundaria, sectorizaciones psicoanalíticas fundamentales, sino que la proto represión es una instancia cultural que se va perfeccionando, como se va perfeccionando ese humor conjetural, se va perfeccionando a lo largo de la vida de un sujeto. Se tendría que perfeccionar a lo largo de la vida de una comunidad, a lo largo de la vida de la humanidad. Pero lo que ocurre es que cuando por poca o precaria, por fracaso de la ternura, por precario establecimiento de una instancia pulsional, no hace frontera, no solamente no hace frontera, proto represión a la agresión, sino que corrompe la agresión, corrompe el instinto, lo pulsionaliza. En este sentido ahí es donde surge la crueldad. La crueldad es una patología de fronteras mal establecidas donde el instinto no solamente no es contenido y acotado por la cultura representada por ese adelantado de la cultura, biológico, que es la pulsión, sino que lo corrompe.

Les voy a dar un ejemplo. Un ejemplo totalmente leído. Estaba leyendo los grandes machos, es un libro sobre los grandes monos. Hay una cosa muy curiosa. Leí que los chimpancé que tienen un $\mathrm{ADN}$ muchos más próximo a la especie humana que a los otros grandes simios, ellos se disfrazan, hacen títeres con la patas para distraer a sus cachorros, ponen ramas, los distraen. Es decir que tiene juegos inventados que no son juegos universales, son juegos distintos. Vale decir que ahí hay algo cultural, pero hay algo más interesante. Un pequeño, un joven adolescente chimpancé está tratando de cascar una nuez arriba de una piedra con un martillo, con otra piedra, entonces pasa alguien de la comunidad, no es ni el padre, ni la madre, se arrima y le enseña cómo se hace. Le da vuelta el martillo, le pone la nuez, hay transmisión de técnicas, hay también transmisión de cultura, hay trabajo. Entonces lo curioso es que este nicho es terriblemente 
cruel, entra en nicho ecológico de otra familia, de otra comunidad chimpancé, entran machos y hembras y se encuentran con diez chimpancé que le salen a marcar el nicho ecológico, se hacen los distraídos, saludan, piden disculpas, hacen gestos, se retiran y se van a su nicho ecológico. Pero después vuelven, cuando no hay nadie y encuentran un joven chimpancé inexperto o uno viejo o uno enfermo y lo muerden torturándolo terriblemente, se vengan de la afrenta de haber sido derrotados por los otros, no lo matan. Está destinado a morir, la muerte, esa injusticia, ese último tormento, lo torturan para que sufra. Esto está comprobado por las personas que trabajan con chimpancé, que es el sujeto más próximo al hombre, parece que es más moderno que el homo sapiens, es una variación evolutiva.

Entonces si este sujeto puede tener precarios juegos y puede tener transmisión de cultura, de trabajo, lo que se puede conjeturar es que tiene una precaria instancia pulsional. Vale decir que algo de la cultura chimpancé va apareciendo, algo del instinto metonímico se va haciendo pulsión precaria. Esa pulsión precaria en el estado que está corrompe el instinto, lo hace cruel. Es decir que sería una forma tal alegórica de lo que yo voy deduciendo del trabajo clínica donde pretendo que lo que digo sean observables conjeturadas. Puede ser que la conjetura me falle, sea por abajo, puede ser que la conjetura sea realmente -y a eso me remito, a lo que Pichón decía- "no se lo vaya a creer cuando lo tome por su hijo y lo quiera como un hijo, pero esta es la verdad". El humor conjetural es como un ducho, no hay que creérselo demasiado.

Entonces a dónde apunto con esto. La crueldad es una patología de fronteras. Puedo dar otro ejemplo, el gato maula y el mísero ratón es un gato doméstico, más allá que su atavismo instintivo lo lleve a matar ratones, mata para jugar. El gato XXX, como juega el gato maula con el mísero ratón, y el gato XXX mata de un solo zarpazo, mata para comer. En este sentido planteo que el instinto, que la agresión se pulsioniza y se corrompe, y esto es la crueldad. Hay que estar muy atento a pensar que la crueldad es instintiva, incluso el sujeto que ha nacido en las peores condiciones del fracaso de la ternura y es cruel, según como le vaya la feria. Y ahí es que es tan importante la escolaridad primaria como una primera institucionalización tantas veces fallida, pero es una instancia de cultura fundamental. Es ahí donde un sujeto puede empezar a darse cuenta que el himno no es meramente cantar ¡Al gran pueblo argentino salud (ele-mental)!, que cantar el himno ciegos o sordos a lo que la letra dice en vez de "ved el trono a la noble igualdad", lo cantamos con mucha emoción. No es que hay que cambiar la letra del himno que corresponde a la época épica que fue construido sancionado en la Asamblea del año 13 -que también estableció algunos otros derechos importantes. Lo cantamos sordos y lo cantamos ciegos a la escena que nos desmiente permanentemente. Entonces al himno se lo canta, pero también habría que estudiarlo. Meto esto porque es un capítulo de un libro que estoy escribiendo de salud mental.

Pero según como le vaya la feria, dentro de la vera crueldad. Digo vera y es contradictorio porque el vero mayor, el torturador, es un individuo que tiene un saber canalla que pretende que el único saber es el de él. Entonces ese saber canalla, ese saber cruel frente a lo distinto lo expulsa, lo aísla, lo odia, y si puede lo elimina, lo eliminará como prójimo, como ciudadano, lo eliminará lisa y llanamente de la vida. Es contrario al saber curioso. El humor conjetural y el saber curioso, es un clásico decir que los sueños para un analista son la vía regia al inconsciente, cuando uno puede trabajar con la culpa de un paciente, con la invalidez de un paciente, al despertar curiosidad con el síndrome de padecimiento, despertar curiosidad, también la culpa, la invalidez, el odio pueden transformarse en vías regias para advertir qué es lo que está condicionando desde el pasado esta situación cruel. 
Voy a abreviar porque quiero terminar. Es breve esto porque esto es lo último que quería encaminar.

A mi me llevó muchos años pasar de la ternura a la crueldad, con lo cual certifico que lo que dice Derridá, la resistencia auto inmune creo que funciona. Todas esas cosas funcionan por eso que llamé, no me puedo extender sobre esto, llamé la disposición universal hacia la crueldad que todos tenemos, la tenemos o latente, por escotomas, porque no vemos, entonces podemos matar con la indiferencia a nuestro paciente; o medio país -el país está partido por el medio casi proporcionalmente por ese eufemismo de la línea de pobreza- medio país o gran mayoría de medio país mata con la indiferencia al otro medio país. Al otro medio país que siente que esa indiferencia le dice porqué no te morís negro de mierda; estás de más. Entonces también un sujeto sobreviviente, la ética de la sobrevivencia nos guste o no nos guste, va a aparecer un oximorón hablar de esto acá, la sobrevivencia del sobreviviente es violenta. La violencia es un oximorón porque niega la ética y la ética niega la violencia, pero no le queda otra. No le queda otra a alguien que no ha tenido ninguna alternativa. Entonces podemos encontrarnos, y esto es mi recaudo para no criminalizar la pobreza, decir que en esas condiciones de injusticia social absoluta, la ética de la sobrevivencia puede llevar a un sujeto a ir camino hacia su propia muerte matando. Matando con una terrible crueldad, pero hay una claudicación ahí, el vero crueldad es impune; se caga en toda ley. Una vez una periodista me preguntó, porqué los analistas que trabajamos en derechos humanos no analizamos torturadores siendo una fuente... Le dije, bueno mire venga dentro de unos días estoy haciendo un (...) sobre la violencia en clínica y entonces le dijo, mire... alguien puede estar mal porque le ha arrebatado su capacidad de decisión o porque él mismo se ha arrebatado, está mal. Alguien puede ser malo porque ha arrebatado la capacidad de decisión de otro. Bueno, mal y malos somos todos. Para el maligno que él cree que es absolutamente hacedor de la ley, del saber cruel, del saber canalla, este tipo no respeta ninguna ley, mal puede respetar las leyes del oficio, un oficio como la clínica psicoanalítica que pretenda establecer cómo fueron los hechos, se cae, se cae directamente. Á él lo recuperan otros estrados, los de la justicia que siempre los trata de evadir.

Otra frase, Lou Andreas Salomé que sabía bastante de esto, hablando de los perversos, de la perversidad de la crueldad, la perversidad de los perversos, decía: "Los perversos tienen acceso al lado oscuro de los sentimientos". Yo pensaba, bueno los analistas también pretendemos tener acceso al lado oscuro de los sentimientos. El lado oscuro de los sentimientos al que aludía Lou Andreas era precisamente a esa patología de frontera, era la crueldad sin ley. Los analistas pretendemos que alguien tenga acceso precisamente sujeto a la ley; entonces hay una pulsión mortal, pulsión tanática que es mortífera. Lo ilustra la guerra como una patología de fronteras. La guerra no solamente ocurre en la frontera pero es paradigmáticamente de las fronteras o de la barbarie civilizadora que va invadiendo fronteras, anulando otras culturas. Entonces hay una pulsión mortífera ilustrada por... que es equivalente a la crueldad y que resulta, esa pulsión mortífera, resulta de un fracaso de lo que llamé globalmente la ternura, pero estoy hablando del fracaso de la cultura, un fracaso de la política, un fracaso de la democracia, de todo lo que no logre resolver la ley del más fuerte.

Dos personas chocan en la esquina, se agarran a trompadas, puedo ser yo uno de ellos, bastante chinche; entonces o lo tiro o me tira, ahí termina. Pero no, le sigo pegando o me sigue pegando, y el público no interviene, los terceros de apelación no intervienen, eso ya es un acto cruel. Es una acto de la agresión de que me chocaron el coche y tengo que pagar no sé cuánto y qué se yo. Una respuesta instintiva, descontrolada, eso es otra cosa, hay una encerrona ahí. 
No importa no hay ningún testigo, pero él mismo no es un testigo que dice 'pará loco, hay que seguir'; este es un sujeto cruel. Bueno esta es la crueldad que tiene que ver con pulsión de muerte mortífera. Esta que Freud estudió en su trabajo cultural y que llevó a ser tan pesimista, pretendiendo ser un optimista que logró ver la verdad, tan pesimista sobre el destino de la humanidad. Yo no es que sea mucho más optimista, digo que no hay razón para no hacer lo que siendo necesario se presenta como imposible. La solución de esto no es una solución psicoanalítica, pero uno trabaja en lo que está haciendo, no puede no trabajar, no meterse, no tener la oportunidad que Freud no tuvo de hacer narración. Es decir intervenir y tratar de modificar y ser modificado en el contexto colectivo.

Pero hay otra pulsión de muerte, la que llamé al principio, con esto termino, pulsión de muerte sutil. En ese pasaje, en esa mutación, no sé si es la palabra más adecuada, pero me parece que es adecuada, en biología se habla de mutación, en esa mutación de lo inexorable metonímico del instinto; metonímico es sin solución de continuidad, lo contrario es metáfora que ya implica una solución de continuidad, es lo mismo de otra manera, de otro lado; la narración pretende ser metafórica, el relato y la referencia, rigurosamente está más cerca de no apartarse de una referencia lo más rigurosa, pero ahí no hay modificaciones, solamente relato histórico. Marx decía; los filósofos en lugar de describir y explicar el mundo tendrían que modificarlo, esas modificaciones es la narración, lo otro es relato. Es muy importante también la historia, es importante consignar los hechos, es más no se podría trabajar si no se consignan los hechos, no se podría hacer narración. Bueno, en es mutación la agresión del instinto, de ese instinto que incorpora desde la noche de los tiempos, incluso ese gran acelerador de la evolución que es la muerte, dos gametas se conjugan en un nuevo prototipo tal vez con alguna modificación y los progenitores afuera, para impulsar la evolución. Bueno, ese instinto también lleva la muerte ya desde la sexuación, de que terminó la partenogénesis de los virus que (...) se multiplican.

Algo de arrastre aparece en la pulsión. Yo creo que esa es la pulsión que Freud describió, la pulsión de muerte como antitética de la vida, pero totalmente ligada, pares ligados, que Freud descubrió en el 20 cuando escribió Mas allá del principio del placer, que fue donde empezó precisamente a trabajar esto. Esto es lo que le permitió -termino con esto- a Freud, esto lo describe magistralmente Stefan Zweig, cuando dice que Freud cuando ya no podía seguir escribiendo, porque Freud no dejó de narrar, abandonó la narración para esos trabajos, después siguió narrando. Hasta narró su propia muerte. Se había comprometido a su médico que cuando él le pidiera le diera la inyección mortal.

Stefan Zweig dice una cosa muy curiosa. Dice que Freud cuando dejó de escribir, cuando ya casi no podía hablar, cuando su perro que era su gran compañía ya se apartaba por el olor que su lesión provocaba, perro de olfato sutil, él considera la muerte como un hecho extrapersonal. Considera la muerte como una situación, se transforma en un observador de la muerte y ordena al médico que le dé la inyección, muere. Esto tiene un correlato en la clínica. Hay un momento, que yo tomo, es un momento que lo describí hace muchos años, antes que se pusiera interesante la noción lacaniana del fin de análisis no como fin de almanaque, sino como finalidad. Descubrí que en un momento dado los pacientes, de bastantes años, sobre todo los analistas que están, tal vez yo mismo, aparecía algo que yo condensaba como (da vuelta el cassette)...

... repetición y síntoma. Es decir me puse a observar que los síntomas originales que trajeron a este paciente al análisis empiezan a reproducirse de nuevo. Curioso dije, qué fracaso fue esto. Hasta que descubrí que esto era una resistencia a algo que el paciente y yo mismo sin advertirlo, acabábamos, nos empezamos a dar cuenta. Supongamos que un análisis marchaba 
como en paralelo y en un momento dado se da cuenta que esas líneas paralelar van convergiendo en un determinado punto. Que no es una topología, ni es... uno se da cuenta que eso va llegando al final. Entonces ese final muchas veces aparece, no como el final de un análisis y todo lo que esto significa, aparece como el malentendido de la muerte. Hay tantas cosas, se ha depositando en esa transferencia tantas aventuras, tanto recorrido se hizo en ese humor conjetural que atraviesa lo posterior y lo anterior a la caída edípica, al fracaso edípico, que esto aparece como una pérdida y aparece lo que llamo el malentendido de la muerte. Entonces si uno no se da cuenta y toma esos síntomas como los empezó a tomar al principio, va tener ciento o seis años más de análisis con esa persona, o tres años, o cuatro... al pedo, inútiles. Al pedo por esto, los franceses cuando hablan de la asociación libre, uno de los pilares, hablan de babardache, literalmente babardache es hablar al pedo, la asociación libre quiere decir eso.

Bueno uno va a tener inútilmente, incluso con malos efectos, un análisis. En cambio si uno advierte esa situación, que ahí hay una cosa que uno mismo la está sintiendo como un malentendido de la muerte, entonces directamente a analizar la resistencia frente a un final inexorable. Vale decir inexorable. No quiere decir que yo me voy a morir o que el paciente se va a morir. Es inexorable porque lo contrario sería realmente una perversión directamente. Mantener...

Tal vez mencione... el poder soberano, una de las cosas esenciales de la crueldad. Después la voy a mencionar nada más.

Entonces qué pasa, uno empieza a analizar ese mal entendido y es una de las pocas oportunidades, no siempre, nunca tiene que ocurrir tal cosa, a veces ocurre, ese analizante empieza a analizar su futura propia muerte. Como empieza a intuir aquello que decía Freud no tiene inscripción, en efecto no la tiene en el inconsciente, pero la tiene en la cultura. Sabemos, como decía Sastre, que se muere el otro, pero también sabemos por quién doblan las campanas, que cuando doblan también están anunciando nuestra propia muerte. Cuando uno asiste a personas que están muriendo, a los años que tengo, con alguna frecuencia, diría una o dos veces por año, yo estoy atendiendo a alguien, un antiguo paciente que va a morir.

Quiero hacer un homenaje a la última persona que atendí, porque tiene que ver con el humor conjetural. Era Ana María Raggio que fue la secretaria académica de la UBA, durante 8 años la atendí, de un cáncer que luchó, luchó con todo coraje, vivió, ella sí que vivió hasta la muerte, no tenía la muerte instalada. Una semana antes dejó el decanato, cuando ya casi no podía caminar. Entonces el día anterior ella me dice (murió pocas horas después) muchas gracias Ulloa usted me ha ayudado mucho, pero hay una injusticia, dice... y yo pensando que ella tenía 50 y pico de años y yo tenía ya 79, le digo, si, si efectivamente -me apresuro- es una injusticia que usted tenga que estar en este lugar y no yo. Entonces ella se pone colorada en su lividez y se ríe, dice -no, discúlpeme; yo quería decir que usted a sus años tenga que estar acompañándome en esto. Entonces yo le digo -mire nosotros ensayamos, a mis años también ensayo esto; es lo más que le puedo decir para acompañarla -en un acto que es totalmente solitario-. Ella me dice sonriéndose -mostraba el temple- por favor Ulloa bájese. Es decir, me liberaba. Murió horas después.

Porqué digo esto. Porque esta mujer terminó su análisis porque terminó con su muerte, pero si no hubiera así en un momento dado cuando se puede intuir algo de la futura propia muerte, pasa una cosa muy curiosa que a mi me ha sido muy útil y es que la muerte deja de ser una instancia de castración, la angustia de castración, la desaparición y el sufrimiento del cuerpo. La muerte empieza a ser vivencia de muerte, donde la palabra vivencia, vida, va dando soporte a la muerte. Entonces dónde descubrí esto. Un paciente analista, hace años, hace un 
viaje a Provincias, estaba muy preocupado por la muerte de su padre que había muerto hacía un tiempo y estaba muy preocupado por su propia muerte. En ese viaje se baja, toma un taxi desde la estación hasta unos kilómetros antes del pueblito, una colina, donde veía el galpón, donde el padre era mecánico y tenía un taller. Lo contempla con nostalgia, donde tuvo sus juegos infantiles, entonces se pone a orinar. Por supuesto aunque era un descampado orina detrás de aquel árbol, ustedes saben que la parte de atrás del árbol donde se orina, y hay una vivencia de su propia muerte. Me cuenta eso; cosa curiosa, es la primera vez que la muerte no me angustia. Yo le pregunto: de qué murió tu padre, lo tuteaba. Él me dice con sorpresa, una cosa que ya me había dicho Bleger muchos años atrás cuando había venido a Rosario porque el padre estaba agonizando. Me dice, murió de una insuficiencia renal. Vale decir que el acto de orinar era casi ayudarlo a morir. Con Bleger que era una persona muy querida, fuimos muy amigos, estábamos en una mesa redonda - esto es el final de mi charla- en la facultad de medicina. Una mesa redonda donde él era el presidente y yo era el secretario. En esa época las mesas tenían presidentes y secretarios, viene alguien, me dice algo, le digo mirá no sé, es de tu casa por tu padre, el padre estaba acá en Rosario, estaba en coma, tenía un cáncer hacía tiempo. Bleger abandona, va a Rosario, viene en colectivo a Rosario, vuelve en varios días y me dice, no sabés la vergüenza que pasé. Venía en colectivo, cada tanto tenía que hacer parar el colectivo, menos mal que era de noche y la gente dormía, tenía unas ganas tremendas de orinar. ¿De qué murió tu papá? Insuficiencia renal. Eso es la muerte.

Tal vez tendría que articular esto con tomar la posta de la novela de lo que no pudo ser.

Muchas gracias.

Estos dos ejemplos muestran el aspecto sutil de la pulsión de muerte incorporada a la dialéctica de la vida. 